\title{
研究小集会報告
}

Yong Hae KIM 教授講演会

\section{世話人 名古屋大学農学部}

磯部 稔

去る平成 15 年 3 月 7 日に, 名古屋大学農学部第一講義 室にて, KAIST (Korea Advanced Institute of Science and Technology, 韓国科学技術院）の Yong Hae Kim 教授を招招きして講演会を開催した，Kim 教授は天然物 化学の分野において多くの業績を上げており, 今回の講演 では「Occurrence of Potent Neuro Toxins of TTX, Chiriquitoxin, and Zetekitoxin」と題し, 最新の研究成果 が披露された，講演の冒頭にKAIST（韓国科学技術院）の 説明をされて，引き続いて研究の紹介が続いた，要旨は次 のとおりである. 中南米に生息するAtelpus 属のカエル は，皮膚に水溶性の毒を有している，コスタリカ産の Atelpus 属のカエルよりフグ毒 (tetrodotoxin, TTX) が同定さ れ,さらに新しい毒成分として, chiriquitoxin が発見され 単離された. Chiriquitoxin の推定分子量の決定は，当初 は Bio-Gel P-2 で行われ，最終的にFABMSによって 392 と決定された，さらに $370 \mathrm{MHz}$ NMR の測定により，下記 のような構造式を提出するに至った，過ヨウ素酸で酸化的 に切断すると, 11-nortetrodotoxin-6,6-diol を与える.

Mosher らによってパナマ産の Atelpus zeteki より, 新 規の水溶性低分子毒として, zetekitoxin (ZTX) が 1969 年に報告されている，TTX は筋肉や脳のナトリゥムチャ ンネルのみを阻害して心筋には作用しない. しかし ZTX は心臟に異常をひき起こす，パナマ産のAtelpus zeteki 入手して，分離精製を試みた，得られた毒は微量のため， 構造決定は困難を極めた。現在, HR-ESIMS の測定により 分子量が 553 と決定され, 重水と重酢酸の混合溶媒中での

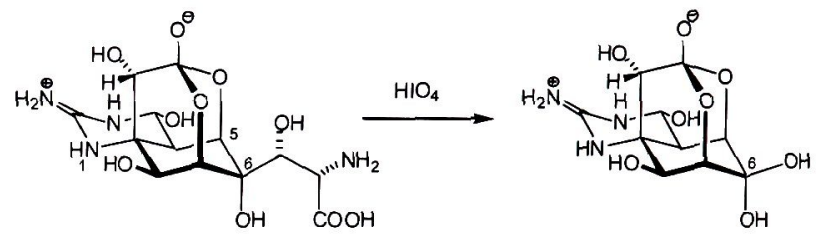

Chiriquitoxin

11-Nortetrodotoxin-6,6-diol

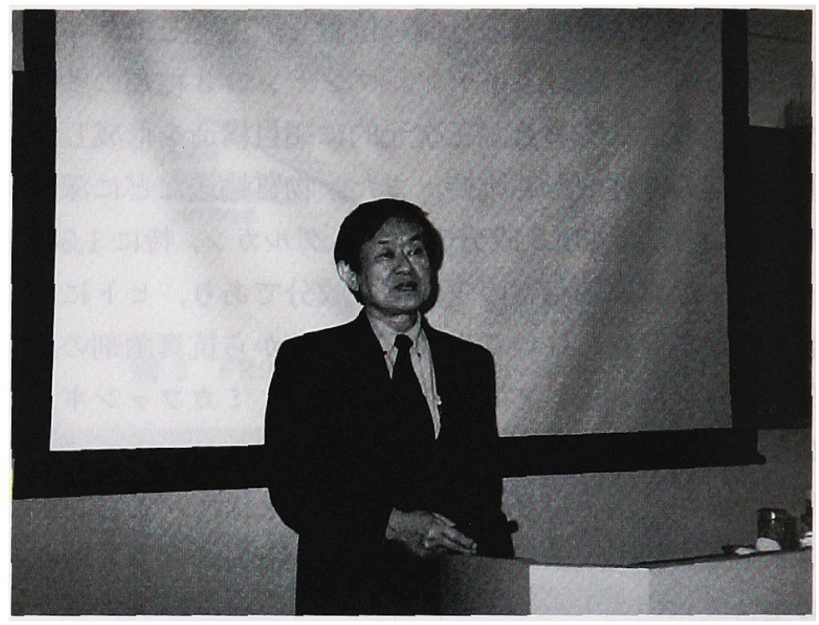

講演者 Yong Hae KIM 教授

NMR 測定により，推定構造を提出するに至っている. Atelpus zeteki が保護条約のため採取困難となっている が, 30 年間構造が未定であった ZTX の構造決定も間近い と思われる。

今回の講演には, 教官, 学生を中心として, 50 名前後が 出席した. 講演後は天然物の分解反応や構造決定の手法に ついての活発な質疑応答が行われた，Kim 教授は日本の 大学で学位を取得されて抢り, 学生の質問にも懇切丁寧に 英語と日本語を織り交ぜて答えられ，盛況のうちに講演は 終了した，最後になりましたが，本講演開催に当たり，で 援助賜りました日本農芸化学会に深謝いたします。

（文責 市川善康） 